\title{
Scenarios of technology adoption towards low-carbon cities
}

Article

Accepted Version

Mohareb, E. A. and Kennedy, C. A. (2014) Scenarios of technology adoption towards low-carbon cities. Energy Policy, 66. pp. 685-693. ISSN 0301-4215 doi:

https://doi.org/10.1016/j.enpol.2013.10.070 Available at https://centaur.reading.ac.uk/44983/

It is advisable to refer to the publisher's version if you intend to cite from the work. See Guidance on citing.

Published version at: http://dx.doi.org/10.1016/j.enpol.2013.10.070

To link to this article DOI: http://dx.doi.org/10.1016/j.enpol.2013.10.070

Publisher: Elsevier

All outputs in CentAUR are protected by Intellectual Property Rights law, including copyright law. Copyright and IPR is retained by the creators or other copyright holders. Terms and conditions for use of this material are defined in the End User Agreement.

\section{www.reading.ac.uk/centaur}

\section{CentAUR}

Central Archive at the University of Reading

Reading's research outputs online 
Cite as: Mohareb, EA \& Kennedy CA, 2014. Scenarios of technology adoption towards low-carbon cities. Energy Policy 66, 685-693

\section{Scenarios of Technology Adoption towards Low-Carbon}

\section{Cities}

Eugene A. Mohareb*, University of Toronto, 35 St. George St., Toronto, ON M5S 1A4

Christopher A. Kennedy, University of Toronto, 35 St. George St., Toronto, ON M5S 1A4

*Corresponding Author; eugene.mohareb@alum.utoronto.ca

\section{$\underline{\text { Acknowledgements }}$}

This study received financial support from people of Canada, through the Natural Sciences and Engineering Research Council. The authors appreciate the data provided by L. Bond, K.Crate, J. Humphries, L. Lewis, M. Nehme, R. Persaud, and J. Webster, as well as the comments provided by C. Andrews, D. Harvey, H. MacLean, and K. Pressnail. 
Cite as: Mohareb, EA \& Kennedy CA, 2014. Scenarios of technology adoption towards low-carbon cities. Energy Policy 66, 685-693

\begin{abstract}
Technological change has often been presented as a salable means by which long-term greenhouse gas (GHG) emission reductions can be achieved. Cities are the future centers of economic growth, with the global population becoming predominantly urban; hence, increases or reductions of GHG emissions are tied to their energy strategies. This research examines the likelihood of one such city (the Greater Toronto Area) achieving an $80 \%$ reduction in GHG emissions through policy-enabled technological change.
\end{abstract}

Emissions are examined from 3 major sources: light duty passenger vehicles, residential buildings and commercial/institutional buildings. Logistic diffusion curves are applied for the adoption of alternative vehicle technologies, building retrofits and high performance new building construction. This research devises high, low and business-as-usual estimates of future technological adoption and finds that even aggressive scenarios are not sufficient to achieve an $80 \%$ reduction in GHG emissions by 2050 . This further highlights the challenges cities and the wider world face in maintaining a relatively stable climate. Urban policy makers must consider that the longer the lag before this transition occurs, the greater the share of GHG emissions mitigation that must addressed through behavioural change in order to meet the 2050 target, which likely poses greater political challenges.

Keywords: Greenhouse Gas Scenarios; Energy Efficiency; Low-Carbon Cities 
Cite as: Mohareb, EA \& Kennedy CA, 2014. Scenarios of technology adoption towards low-carbon cities. Energy Policy 66, 685-693

\subsection{Introduction}

Cities are expected to play an important role in climate change mitigation, given their high current contribution to greenhouse gas $(\mathrm{GHG})$ emissions and the projection that population and economic activity will continue to gravitate towards them (Kennedy et al, 2009; Hoornweg et al, 2011). Many global cities have already recognized their importance in addressing climate change and have begun to formulate policy for achieving long range targets at lower emissions levels. Technological change has often been held as a desirable and feasible means by which industrialized societies can transition to low-carbon economies (Pacala and Socolow, 2004; Meinshausen et al, 2009; Jacobson and Delucchi, 2011). Technological measures include fuel switching (i.e. coal to natural gas), adoption of renewable energy sources, the pursuit of carbon sequestration (through both natural and artificial pathways) and the transition to higher efficiency conversion technologies. How far - and how fast - new technologies (and the policies intended to stimulate their adoption) can reduce the emissions intensity of an urban region towards a level that is consistent with a low-risk climate change scenario has yet to be answered at an urban scale.

The Pathways to Urban Reductions in Greenhouse gas Emissions modeling tool, or PURGE, can be used to estimate the diffusion of these technologies in the urban context and the impact on future GHG emissions. The development of the PURGE model is described in Mohareb and Kennedy (2012); the model is applied in that instance to quantify future business-as-usual (BAU) GHG emissions from the building, transportation and waste sectors using publically available data on technology stocks, energy consumption and population/economic growth. It should be noted that the model neglects the industrial sector and does not directly account for behavioural change. PURGE allows the examination of trends in technology adoption consistent with policy measures being applied by local and 
Cite as: Mohareb, EA \& Kennedy CA, 2014. Scenarios of technology adoption towards low-carbon cities. Energy Policy 66, 685-693

senior levels of government, through the development of sigmoidal (logistic) diffusion curves (Grubler, 1997). These diffusion curves capture components of technological adoption such as growing awareness of the technology and price decline due to increases in production (i.e. economies of scale; Grubler et al, 1999). A summary of the PURGE model's methodology is provided in Supplementary Materials Section S1. In this instance, projections are applied to the Greater Toronto Area (GTA), a region that is representative of much of North America given that post-WWII infrastructure investments are a primary influence its urban landscape. Examples of post-WWII infrastructure in this case include suburban development with segregated land uses, dependent on extensive road networks to enable the automobile as the primary mode of transportation. The Greater Toronto Area is a $7,150 \mathrm{~km}^{2}$ region incorporating the City of Toronto (Canada's largest city), and four neighbouring jurisdictions. These jurisdictions partially act as commuter cities to Toronto and its central business district, but have also developed as economic centres in their own right. Characteristics such as low population density, high proportion of single-family dwellings and reliance on automobiles all present a significant challenge to GHG mitigation within the City of Toronto, and more prominently in these nearby regional municipalities.

The emission reduction gaps that low carbon technologies must bridge are expansive; Meinshausen and others (2009) suggest that a peak $\mathrm{CO}_{2} \mathrm{e}$ concentration of $450 \mathrm{ppm}$ would likely limit warming to below $2^{\circ} \mathrm{C}$, avoiding some of the most severe consequences of climate change. To achieve this concentration, a policy target suggested by the Intergovernmental Panel on Climate Change (IPCC) states that Annex I nations (identified under the Kyoto Protocol) need to reduce their GHG emissions by 80-95\% from a1990 baseline by 2050 (IPCC 2007). Our previous study of current energy and technology policies in the Greater Toronto Area (GTA; the region surrounding the C40 city; C40 Cities, 2011) 
Cite as: Mohareb, EA \& Kennedy CA, 2014. Scenarios of technology adoption towards low-carbon cities. Energy Policy 66, 685-693

examined expected GHG emissions reductions under a BAU scenario and found reduce emissions from 35 in 2010 to $24 \mathrm{Mt} \mathrm{CO}_{2} \mathrm{e}$ by 2050, largely as a consequence of the decarbonizing of the provincial electricity grid (from 0.17 to $0.02 \mathrm{~kg} \mathrm{CO}_{2} \mathrm{e} / \mathrm{kWh}$; Mohareb and Kennedy, 2012). More aggressive approaches must be taken in the major emitting sectors (transportation and buildings) in order to achieve the $80 \%$ reduction target by 2050 , i.e., $7 \mathrm{Mt}$ per annum (applying a 1990 baseline using Statistics Canada, 2006 and Harvey, 1993).

This paper discusses the use of the PURGE model to examine a number of different mitigation scenarios that have been developed within the literature or from public data sources, allowing the exploration of urban emissions under possible alternative technology futures (Table 1). The scenarios assessed include the three largest sectors currently contributing to direct GHG emissions in the GTA (focusing on scope 1 and 2 emissions, neglecting emissions associated with materials, food, processing of fuel and exportation of wastes): private transportation, residential buildings and commercial/institutional (C/I) buildings. To provide context to how much the building / transportation sectors contribute to regional GHG emissions, total emissions from the GTA from buildings, transportation (ground and aviation), industry (both process- and energy-related emissions), and waste in 2009 were estimated to be $54 \mathrm{Mt} \mathrm{CO}_{2} \mathrm{e}$, whereas the sectors assessed here are estimated to release $37 \mathrm{Mt} \mathrm{CO}_{2} \mathrm{e}$ in 2010 using the PURGE model estimates (Civic Action, 2011). Further analysis of the impacts of specific technology transition pathways is provided by varying the underlying drivers of the dynamics of emissions (population and economic growth), as well as the electricity grid emission intensity that contributes to some upstream emissions. While some of the strategies provided below can be attributable to provincial or federal governments, they do not represent a comprehensive list of scenarios that these higher levels of government may take. However, these scenarios do capture programs (home energy 
Cite as: Mohareb, EA \& Kennedy CA, 2014. Scenarios of technology adoption towards low-carbon cities.

Energy Policy 66, 685-693

retrofits, incentives for battery-based vehicle adoption, investment in public transit) that have been or are currently partially funded by the provincial and/or federal government.

Table 1: Summary of Scenario Options Applied for the GTA to the PURGE Model

\begin{tabular}{|c|c|}
\hline Scenario & Description \\
\hline \multicolumn{2}{|r|}{ Transportation } \\
\hline T1 (BAU) & $30 / 30 / 40 \rightarrow$ BEV/HEV/PHEV \\
\hline T2 (High) & $30 / 20$ / 20 / 10 / $20 \rightarrow$ ICE-T/ HEV / Diesel / PHEV / ICE conventional \\
\hline T3 (Low) & $40 / 30 / 30 \rightarrow \mathrm{HFCV} / \mathrm{BEV} / \mathrm{PHEV}$ \\
\hline \multicolumn{2}{|r|}{ Residential Buildings } \\
\hline $\begin{array}{l}\text { Building Code - } \\
\text { Current (BAU) }\end{array}$ & $35 \%$ reduction in building code in 2011 \\
\hline $\begin{array}{l}\text { Building Code - } \\
\text { Aggressive (Low) }\end{array}$ & $35 \%$ reduction in building code in $2011,25 \%$ in $2016,25 \%$ in 2016 \\
\hline $\begin{array}{l}\text { BR1- Option } 1 \\
\text { (BAU) }\end{array}$ & Average of ECOEnergy retrofits savings applied by home vintage/type \\
\hline $\begin{array}{l}\text { BR2- Option } 2 \\
\text { (High) }\end{array}$ & $\begin{array}{l}\text { Average of bottom } 50 \% \text { of ECOEnergy retrofits savings applied by home } \\
\text { vintage/type }\end{array}$ \\
\hline $\begin{array}{l}\text { BR3- Option } 3 \\
\text { (Low) }\end{array}$ & $\begin{array}{l}\text { Average of top 50\% of ECOEnergy retrofits savings applied by home } \\
\text { vintage/type }\end{array}$ \\
\hline \multicolumn{2}{|r|}{ Commercial/Institutional Buildings } \\
\hline $\begin{array}{l}\text { Retrofits - Current } \\
\text { (BAU) }\end{array}$ & $10 \%$ reduction in building by 2014 \\
\hline $\begin{array}{l}\text { Retrofits - } \\
\text { Aggressive } \\
\text { (Low) }\end{array}$ & McKinsey projections by 2025 \\
\hline $\begin{array}{l}\text { CIB1 } \\
\text { (BAU) }\end{array}$ & $\begin{array}{l}\text { New buildings with average energy use intensity of comparable LEED } \\
\text { certified buildings }\end{array}$ \\
\hline CIB2 (Low) & $\begin{array}{l}\text { New buildings with greatest reduction energy use intensity of comparable } \\
\text { LEED certified buildings }\end{array}$ \\
\hline \multicolumn{2}{|r|}{ Electricity } \\
\hline $\begin{array}{l}\text { Electricity-1 } \\
\text { (BAU) }\end{array}$ & $\begin{array}{l}\text { Current projection of grid intensity reduction to } 2015 \text {, maintained } 2015 \text { - } \\
2050\end{array}$ \\
\hline $\begin{array}{l}\text { Electricity-2 } \\
\text { (High) }\end{array}$ & 2010 grid intensity projected to 2050 \\
\hline $\begin{array}{l}\text { Electricity-3 } \\
\text { (Low) }\end{array}$ & $\begin{array}{l}\text { Current projection of grid intensity reduction to } 2015 \text {, carbon-free grid by } \\
2050\end{array}$ \\
\hline
\end{tabular}

BAU = Business-As-Usual; BEV = Battery Electric Vehicles; HEV = Hybrid Electric Vehicles; PHEV = Plug-in Hybrid Electric Vehicles; $\mathrm{T}-\mathrm{ICEV}=$ Turbo Internal Combustion Engine Vehicles; Hydrogen Fuel Cell Vehicles; LEED = Leadership in Energy and Environmental Design 
Cite as: Mohareb, EA \& Kennedy CA, 2014. Scenarios of technology adoption towards low-carbon cities. Energy Policy 66, 685-693

\subsection{Urban Scenarios for GHG Mitigation through Technological Change}

Future GHG emissions from the GTA, and indeed all global cities, will greatly depend on three primary urban characteristics; population growth, economic growth and technology stock. Population growth stimulates demand for all sources of GHG emissions, especially energy services provided within the three main sectors (transportation, residential buildings and commercial/institutional buildings) of urban GHG emissions. While current GTA population projections estimate $1.4 \%$ growth per annum, it is worthwhile to examine slightly higher and lower growth estimates (Ontario Ministry of Finance, 2010). For this purpose, 1\% and $2 \%$ scenarios have been selected to examine the sensitivity to population growth.

Economic growth is an input into the institutional/commercial buildings model, as well as the vehicle purchase model (providing further insight into the sensitivity of urban emissions). Within the past decade, annual economic growth has averaged 1.7\% (Statistics Canada, 2011). However, there is currently uncertainty in growth projections in many mature economies; as a result, growth estimates of $1 \%$ (more conservative) and $3 \%$ (on the order of that desired in post-industrial societies) are applied as well. In addition to population and GDP growth, details on the technology stock scenarios developed for the three major sectors are described below.

\subsection{Transportation}

Historic vehicle purchase data was used to compile existing vehicle stocks, followed by the adoption of a variety of alternative vehicle technologies post-2010. Numerous technological options are currently being developed to replace conventional internal combustion engines vehicles (ICEVs), generally requiring electricity as a source of secondary energy. It has been proposed for some time that future delivery of tertiary energy (motive services) will be 
Cite as: Mohareb, EA \& Kennedy CA, 2014. Scenarios of technology adoption towards low-carbon cities. Energy Policy 66, 685-693

through one of three pathways: electric motors (powered directly by energy storage from the electricity grid), biofuel combustion or through the conversion of hydrogen to electricity using fuel cell technology (Chan, 2002; Lave and MacLean, 2003; Romm, 2006). The rate of adoption in the scenarios below is derived from the recent uptake of Hybrid Electric Vehicle (HEV) technology (assuming this is transferable amongst other battery-based technology, and hydrogen-based vehicles will eventually follow a similar rate of adoption). A selection of existing studies (described below) that are consistent with current projections of the evolution of passenger vehicle technologies (see Chu and Majumder, 2012) provide estimates on the future composition of the private vehicle stock are applied for scenario development in the PURGE model. Summaries of the scenarios applied to the PURGE model are illustrated in Figure 1.

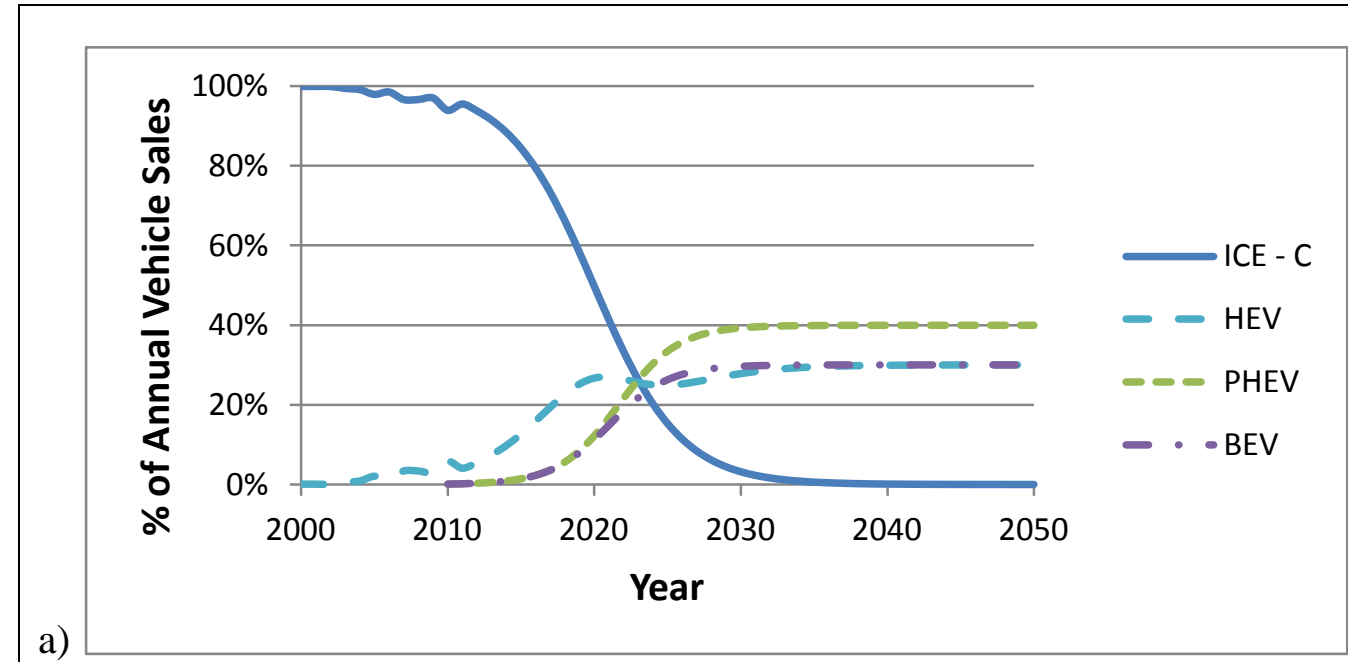


Cite as: Mohareb, EA \& Kennedy CA, 2014. Scenarios of technology adoption towards low-carbon cities. Energy Policy 66, 685-693

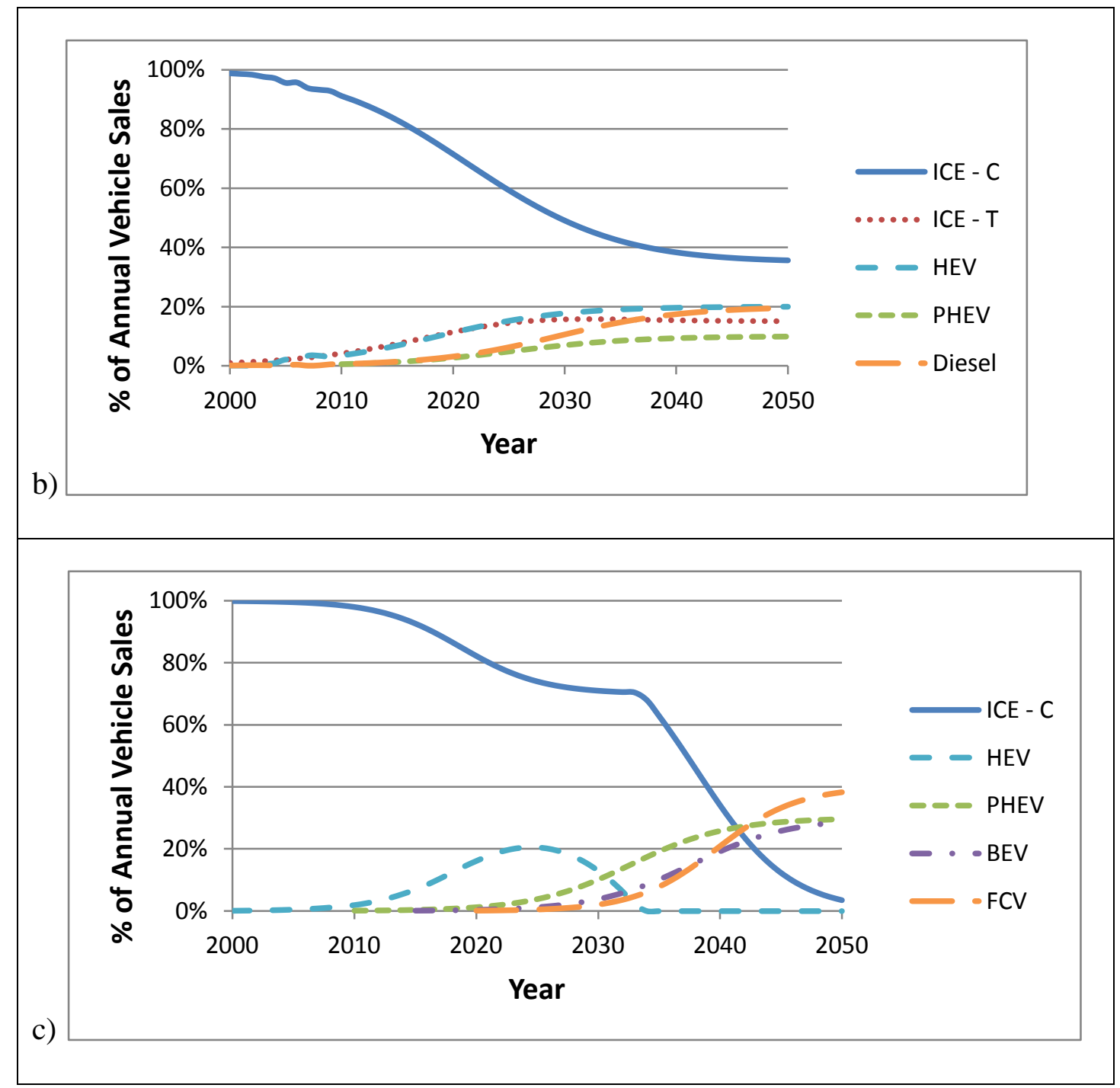

Figure 1: a) Scenario T1, b) Scenario T2 and c) Scenario T3 for Vehicle Technology Adoption Applied to the PURGE Model; ICE - C = Internal Combustion Engine Conventional; ICE $-\mathrm{T}=$ Internal Combustion Engine - Turbo; HEV = Hybrid Electric Vehicle; PHEV = Plug-in Hybrid Electric Vehicle; BEV = Battery Electric Vehicle The baseline scenario (T1) uses the assumption that battery-based vehicles dominate the personal vehicle market (based on current provincial government policy; Government of Ontario, 2009) and constraints with hydrogen fuel cell vehicles (HFCVs) prove cost prohibitive (Romm, 2004). Range limitations and cost for Battery Electric Vehicles (BEVs) and Plug-in Hybrid Electric Vehicles (PHEVs), respectively, are assumed to prevent their 
Cite as: Mohareb, EA \& Kennedy CA, 2014. Scenarios of technology adoption towards low-carbon cities. Energy Policy 66, 685-693

complete market domination, resulting in the persistence of Hybrid Electric Vehicles (HEVs) for the long term (Pearre et al, 2011; LFEE, 2008). PHEVs are presumed to possess a greater market share as they provide both electricity-based (presumably low carbon) and high efficiency fuel-based transportation (addressing range anxiety).

A second scenario is developed from MIT's Laboratory for Energy and Environment (LFEE) report, which presents projections for vehicle technology stock to 2035 (LFEE, 2008). One such projection includes a "no clear winner" future in which the market is comprised of a mixture of vehicles, including conventional ICEVs, turbo-charged gasoline ICEVs, HEVs, diesel ICEVs, PHEVs, with ICE-based vehicles still dominating annual vehicle sales by 2050 (extrapolating from the figures provided in that study). This scenario (T2) is useful to estimate the impacts of maintaining ICEVs in the vehicle stock in the long term and may be realistic if there is continued reluctance to adopt battery-based vehicles (i.e. if pessimistic projected lags in the supply-side adoption hold true -such as the 15-20 years to achieve 30\% of annual sales estimated in the LFEE study). Support for this projection is given by the suggestion that vehicle technologies have historically taken 10-30 years before they are adopted in $50 \%$ of new additions to the vehicle stock (Nakicenovic, 1986); however, relative cost differences between conventional ICEVs and alternatives could be reduced through increases in the price of oil relative to these alternatives, accelerating the adoption of nonICEV options. The MIT study assumes the price of oil and its availability would not negatively impact demand.

A final transportation scenario (T3) is applied to the GTA using the International Energy Association (IEA) and Organization for Economic Cooperation and Development (OECD) projection of global vehicle sales to 2050 under their BLUE Map scenario (IEA, 2009). This scenario suggests that, by 2050 , vehicle sales of conventional gasoline vehicles will be 
Cite as: Mohareb, EA \& Kennedy CA, 2014. Scenarios of technology adoption towards low-carbon cities. Energy Policy 66, 685-693

negligible. While HEVs serve as a transitional technology, HFCV and BEVs would provide the majority of vehicle sales by mid-century, with HFCVs providing the added range formerly provided by HEVs (and perhaps battery electric vehicles with significantly improved energy storage). This scenario assumes that costs of HFCV technology will decline dramatically over the long term, and that challenges in providing the necessary infrastructure (such fuelling stations, hydrogen distribution networks, storage/leakage, and low-carbon hydrogen production) will be overcome.

\subsection{Buildings}

The existing building stock and energy consumption data used here are compiled from federal government censuses and surveys (see Table S2.1 in Supplementary Materials Section 2). Buildings present a challenge to reducing greenhouse gas emissions (IPCC 2007); most newly constructed residential and commercial properties, once erected, are maintained for the long term (annual demolition permits in the City of Toronto amounted to roughly one quarter of one percent of the residential building stock between 2000-2010; City of Toronto, 2011). Moreover, there are limitations to efficiency gains that can be made through conventional retrofits (Dong et al, 2005). As a result, building energy demand can become "locked-in", requiring changes in technology, behaviour or carbon intensity of the energy source in order to achieve deeper reductions (on the order of $80 \%$ ) in GHG emissions; this emphasizes the need to dramatically reduce energy demand in new buildings in the short term. However, it is of interest to examine the effects of different technological scenarios to reduce GHG emissions.

\subsubsection{Residential Building Scenarios}


Cite as: Mohareb, EA \& Kennedy CA, 2014. Scenarios of technology adoption towards low-carbon cities. Energy Policy 66, 685-693

Residential buildings (whose numbers are driven by population growth in the PURGE model as occupancy rates are held constant) are projected to increase in number in the coming years (Ontario Ministry of Finance, 2010). As a result, two principal strategies are available to achieve direct reductions in absolute emissions; retrofits and improvements to the building energy code. Additionally, indirect reduction of emissions through the lowering the carbon intensity of energy used is also an option, such as through the increased use of nuclear, hydroelectric and renewables in electricity generation or perhaps through the introduction of upgraded biogas to the natural gas distribution network. The focus here will be on the reduction of onsite energy demand through end-use technology improvements.

Retrofit data collected from the GTA is available from Natural Resource Canada's (NRCan) ecoENERGY Retrofit program (Natural Resources Canada, 2011). These data are provided from energy audits of residences in the GTA between 2006 and 2011, both prior to and after retrofits. Energy consumption is estimated using energy modeling software (HOT 2000), and data is available for both Single Family Units (SFU) and apartments. The types of retrofits that were pursued through this program included reduced air leakage, geoexchange-based space conditioning systems, furnace efficiency improvements and upgraded building envelopes.

Data on energy savings from retrofits are categorized by building type (apartment, SFUattached, and SFU-detached), vintage (see breakdown in Supplementary Materials Section 2 Table S2.1) and energy source (natural gas or electricity). New buildings are assumed to be included amongst those to be retrofitted 10 years after their construction. Three scenarios are developed using these vintage and fuel type data; average savings from the ecoENERGY program (Scenario BR1), average of data points below the median (BR2) and average above the median (BR3). These provide an aggregation of the retrofits that homeowners have 
Cite as: Mohareb, EA \& Kennedy CA, 2014. Scenarios of technology adoption towards low-carbon cities. Energy Policy 66, 685-693

pursued given previous financial incentives and are assumed to be representative of what can be accomplished in the future. All of these scenarios are assumed to diffuse logistically (the rate of adoption employs a regression of recent retrofits), with an ambitious target of $100 \%$ adoption by 2050 (Figure 2) to provide the best achievable result of technology adoption. It should be noted that the ecoENERGY audit program has now concluded and that extrapolating the rate of adoption from what was observed during its existence is optimistic. However, the potential remains that similar future programs will be initiated.

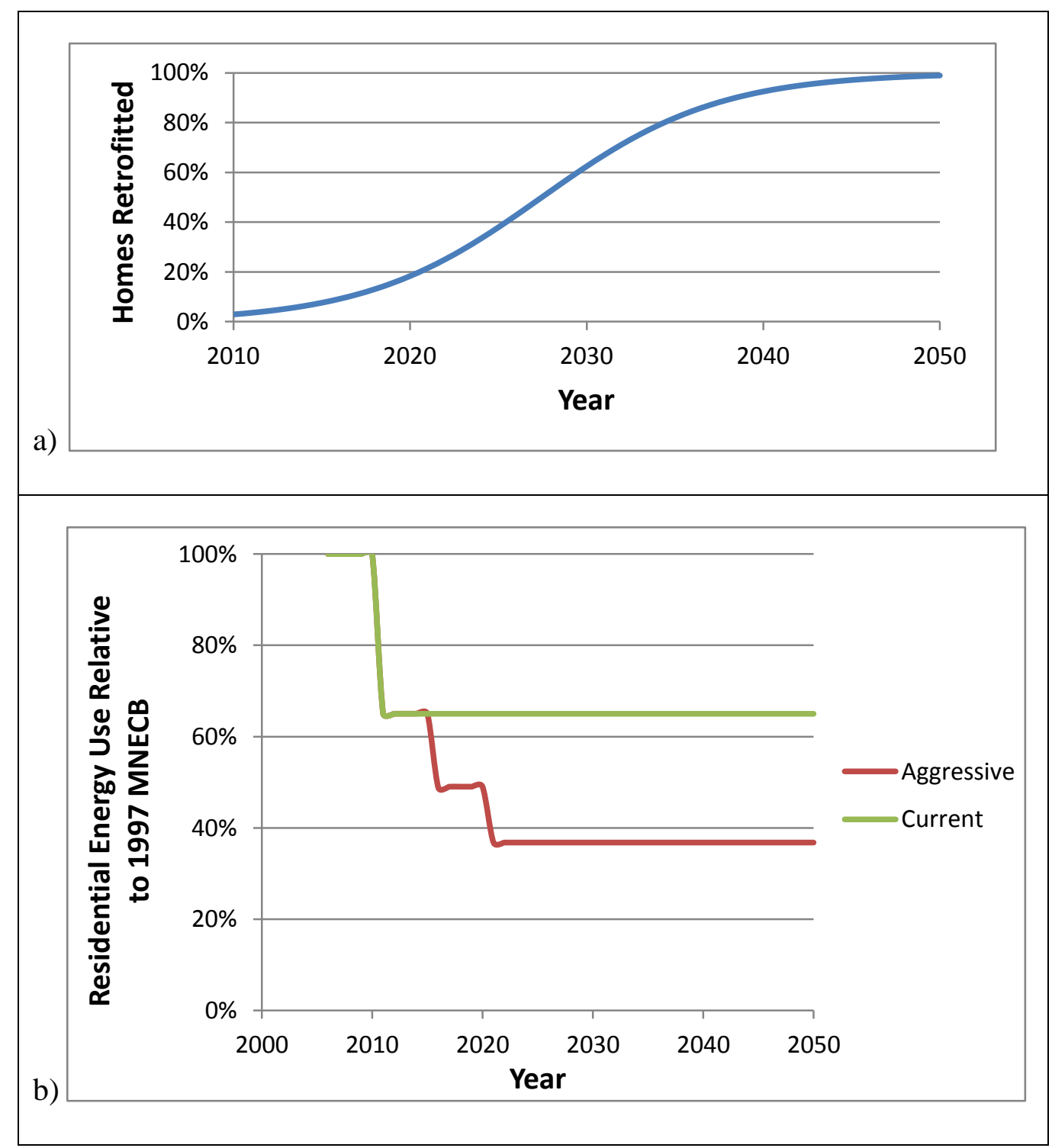

Figure 1: a) Diffusion of Home Retrofits; b) Building Code Changes into the GTA Housing Stock 
Cite as: Mohareb, EA \& Kennedy CA, 2014. Scenarios of technology adoption towards low-carbon cities. Energy Policy 66, 685-693

Additionally, building code changes are assessed for their impact on GHG emissions. In a "current" approach, a 35\% reduction in building energy use is modeled for 2010 onwards (per the recent updates in the Ontario Building Code; Ministry of Municipal Affairs and Housing, 2010). An aggressive scenario assessed will apply the $35 \%$ reduction from current standards, followed by two successive 25\% reductions in 2016 and 2021 (Figure 2b).

\subsubsection{Commercial \& Institutional Buildings Scenarios}

Commercial and institutional (C/I) sector emissions are assumed to be related to GDP growth, with the added assumption that the floor space intensity ( $\mathrm{m}^{2} /$ GDP) of sub-sectors are constant in the long term. As a result, rate of emission increases is proportional to GDP growth for each sector. This is moderated by improvements to the building practices (decreasing energy intensity) and retrofits to existing buildings.

The non-profit GTA urban issues advocacy group Civic Action has set a reduction target in commercial sector energy use of $10 \%$ by 2014 (Civic Action, 2012). As this is the only program working to address GHG emissions from the commercial and institutional sectors, their target is applied as a base scenario. It is important to note that Civic Action does not have any direct control over policy and their target may not be widely accepted and representative of community efforts; as a result, this may be an optimistic projection. A more aggressive scenario is developed using a report from McKinsey \& Co (2009); estimates are presented on energy reductions possible by applying strategies that have a positive net present value under their analysis. These energy use reductions are applied to the $10 \mathrm{sub}-$ categories used in the PURGE model, with diffusion completed by 2025. An illustration of the reduction of energy intensity through retrofitting using office buildings as an example is seen in Figure 3a. 
Cite as: Mohareb, EA \& Kennedy CA, 2014. Scenarios of technology adoption towards low-carbon cities. Energy Policy 66, 685-693

A base case for new construction (CIB1) is assumed to apply the average LEED new construction energy use for relevant building types, taken from the US Green Building Council database (USGBC, 2011). An aggressive new construction scenario is also applied (CIB2) using the best case from each sector from the USGBC database. These practices are assumed to diffuse logistically into building practices in all sectors, though with a slower rate of adoption than is used in CIB1 scenario (see Figure 3b for an illustration for office buildings; not all sectors are presumed to be as successful in reducing energy demand - see Supplementary Materials Section S2).

a)

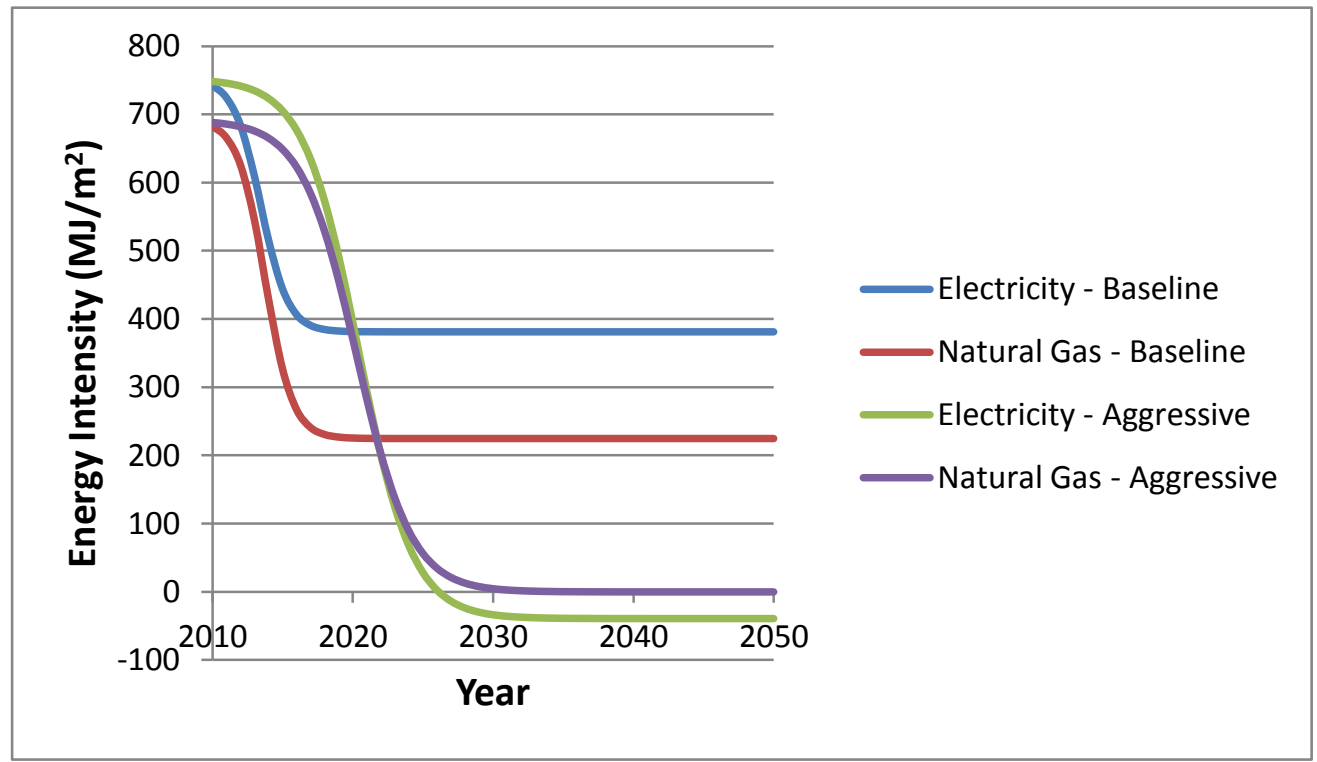

b) 
Cite as: Mohareb, EA \& Kennedy CA, 2014. Scenarios of technology adoption towards low-carbon cities. Energy Policy 66, 685-693

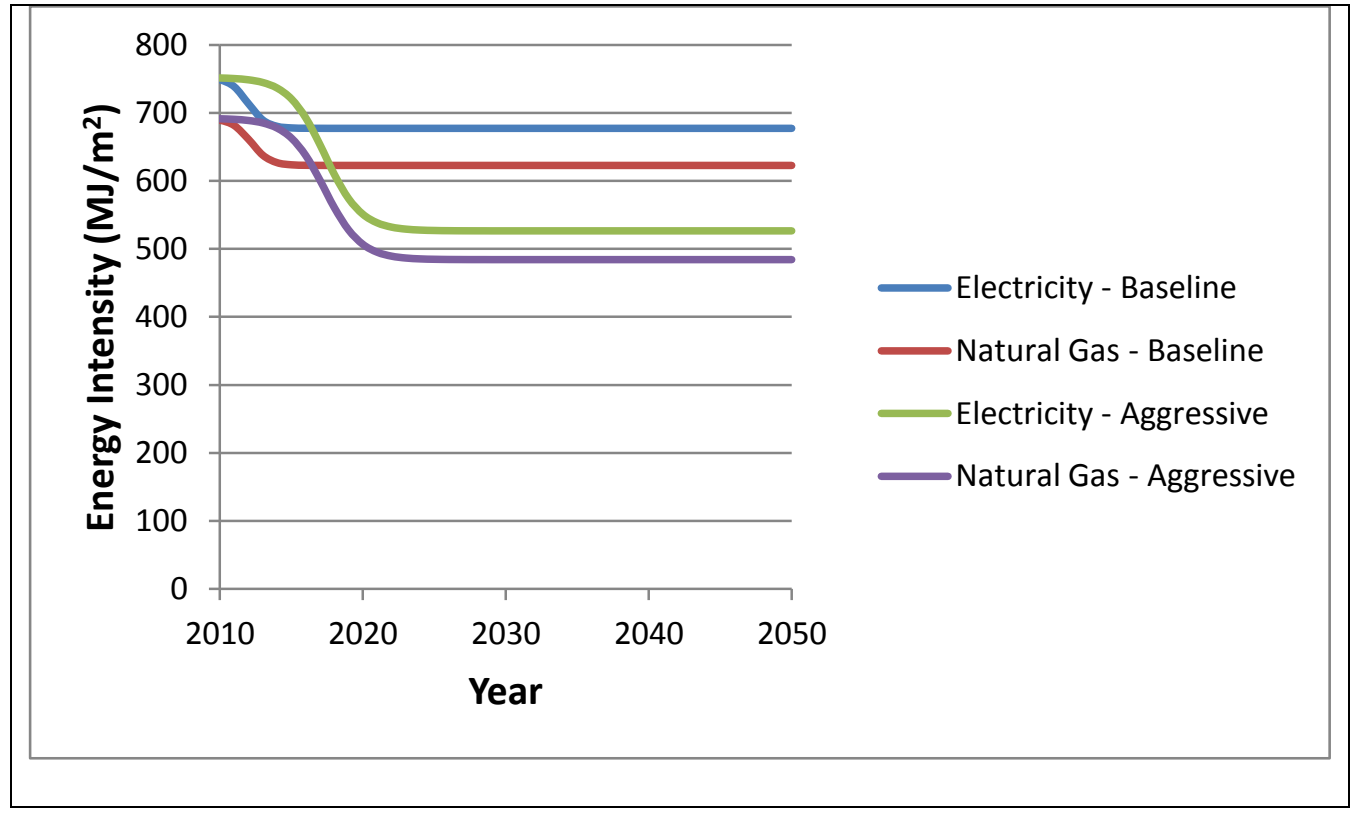

Figure 2: a) Scenarios for Energy Intensity of New Office Construction and b) Energy Intensity of Existing Office Buildings

\subsection{Electricity}

Ontario's electricity grid currently relied on low-carbon sources (nuclear, hydro and wind) for $81.7 \%$ percent of its generation in 2011 (IESO, 2012). The current Ontario government is in the process of removing coal-fired generation from the provincial electricity grid, which will reduce the GHG emissions intensity even further. The current target year for achieving this goal is 2014. In order to satisfy the need for peaking loads, the Ontario government has encouraged the shift from coal to natural gas. The ultimate goal is for natural gas to support the development of renewable energy in the province, providing the flexibility of quick deployment when intermittent power sources are unavailable (Ontario Ministry of Energy, 2011). However, it is not presently clear when the shift away from natural gas will occur. As a result, current estimates of grid intensity reductions represent the baseline scenario, where the 2014 grid intensity is maintained to 2050 (E1). 
Cite as: Mohareb, EA \& Kennedy CA, 2014. Scenarios of technology adoption towards low-carbon cities. Energy Policy 66, 685-693

Uncertainty exists regarding the political will to maintain a course of the replacement of coalfired electricity generation with less carbon-intensive options. An alternative scenario is presented where 2010 grid intensity is maintained in the long term (E2).

Finally, a scenario that leads to a carbon-free electricity grid by 2050 is also applied (E3). The means to achieve this reduction could follow a number of different approaches, including increasing the contribution of nuclear generation, coupling renewable electricity with energy storage options (e.g. electric vehicles, pumped storage), increased importation of hydroelectricity from neighbouring jurisdictions and greater adoption of (net-zero) biomass electricity generation (Möllersten et al, 2003; Pacala and Socolow, 2004; Krajačić et al, 2011). The adoption of battery-based vehicles could facilitate the transition to low-carbon energy, with private vehicles providing storage capacity of intermittent renewable energy generation. While adoption of large, centralized generating technologies is likely to follow a reduction pathway that resembles a step function (such as the replacement of coal-fired generation with natural gas), smaller-scale, distributed energy technologies (battery-based vehicles, renewables and fuel switching) may better be approximated by sigmoidal diffusion. The latter, more conservative adoption rate is applied.

\subsection{Results \& Discussion}

Our BAU, "high" and "low" case forecasts for scope 1 and 2 GTA GHG emissions are presented in Figure 4. These incorporate the best- and worst-case scenarios that were modeled in each sector (residential buildings, non-residential buildings and private transportation). Examining the high scenario, the greatest source of emissions (50\% of 2050 emissions) is from the commercial/institutional building sector, stemming from continued growth in GDP. The next greatest contribution (30\% of 2050 emissions) comes from the 
Cite as: Mohareb, EA \& Kennedy CA, 2014. Scenarios of technology adoption towards low-carbon cities. Energy Policy 66, 685-693

transportation sector, attributable to increased GDP and the application of a scenario which incorporated significant ICE vehicles. Finally, residential buildings contribute roughly $20 \%$ of 2050 emissions in the "high" scenario, owing to higher carbon electricity, modest building code improvements and relatively high annual population growth (2\%). This conservative case suggests a $66 \%$ increase from the $2010 \mathrm{GHG}$ emissions estimate.

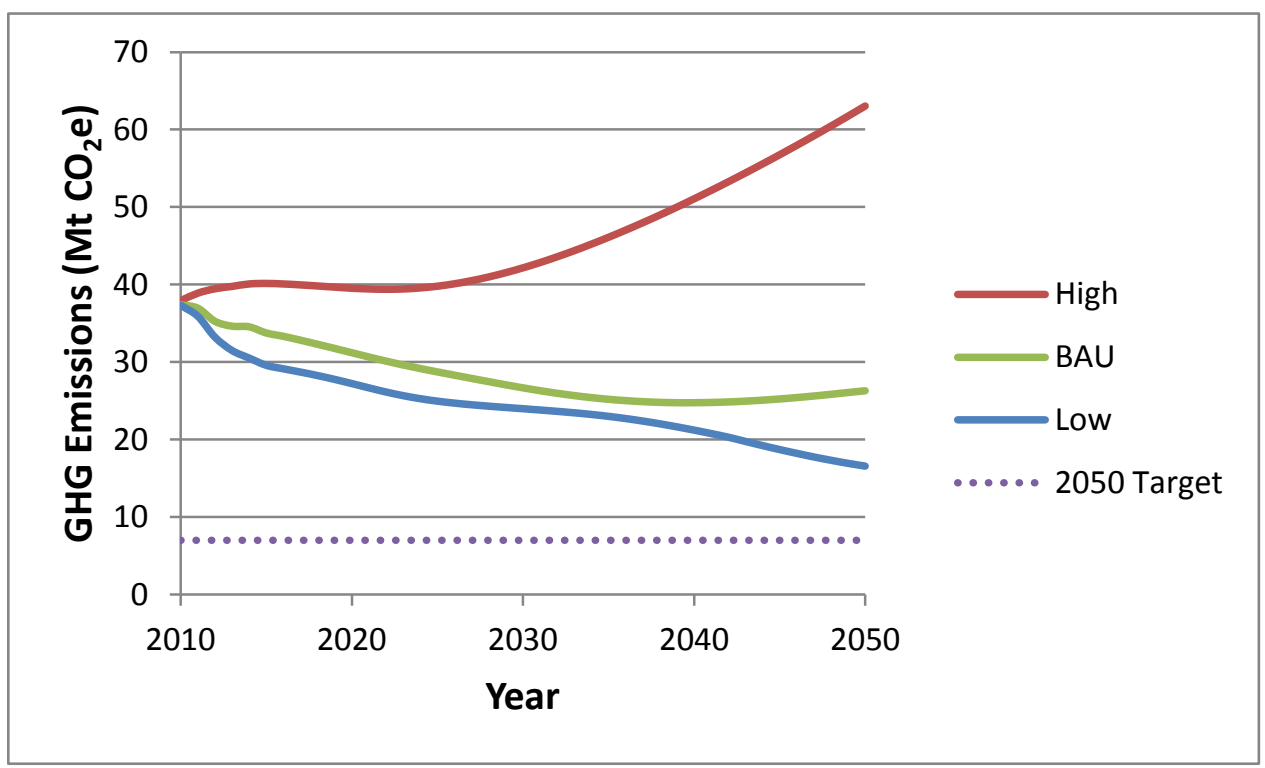

Figure 4: High (2\% population, 3\% economic growth, Electricity-2, T2, BR2, CIB1, current residential building code, current $\mathrm{C} / \mathrm{I}$ new construction trends and retrofits) and low ( $0.5 \%$ population growth, $1 \%$ economic growth, Electricity-3, T3, BR3, CIB3, aggressive residential building code changes, aggressive $\mathrm{C} / \mathrm{I}$ new construction trends and retrofits) emissions scenarios for the GTA from the PURGE model

The "low" case is a 60\% reduction from the GTA 2010 emissions baseline. The greatest source of emissions reductions relative to the "high" case is in the C/I sector. These can be attributable to the aggressive cuts in energy intensity in new buildings, deeper efficiency gains from retrofits and low GDP/population growth. No scenario assessed above was able to reach the regional emission reduction target of $7 \mathrm{Mt} \mathrm{CO}_{2}$ ( $80 \%$ below the 1990 baseline). 
Cite as: Mohareb, EA \& Kennedy CA, 2014. Scenarios of technology adoption towards low-carbon cities. Energy Policy 66, 685-693

Results from all scenarios from the three sectors assessed are presented in greater detail in Figure 5.

a)

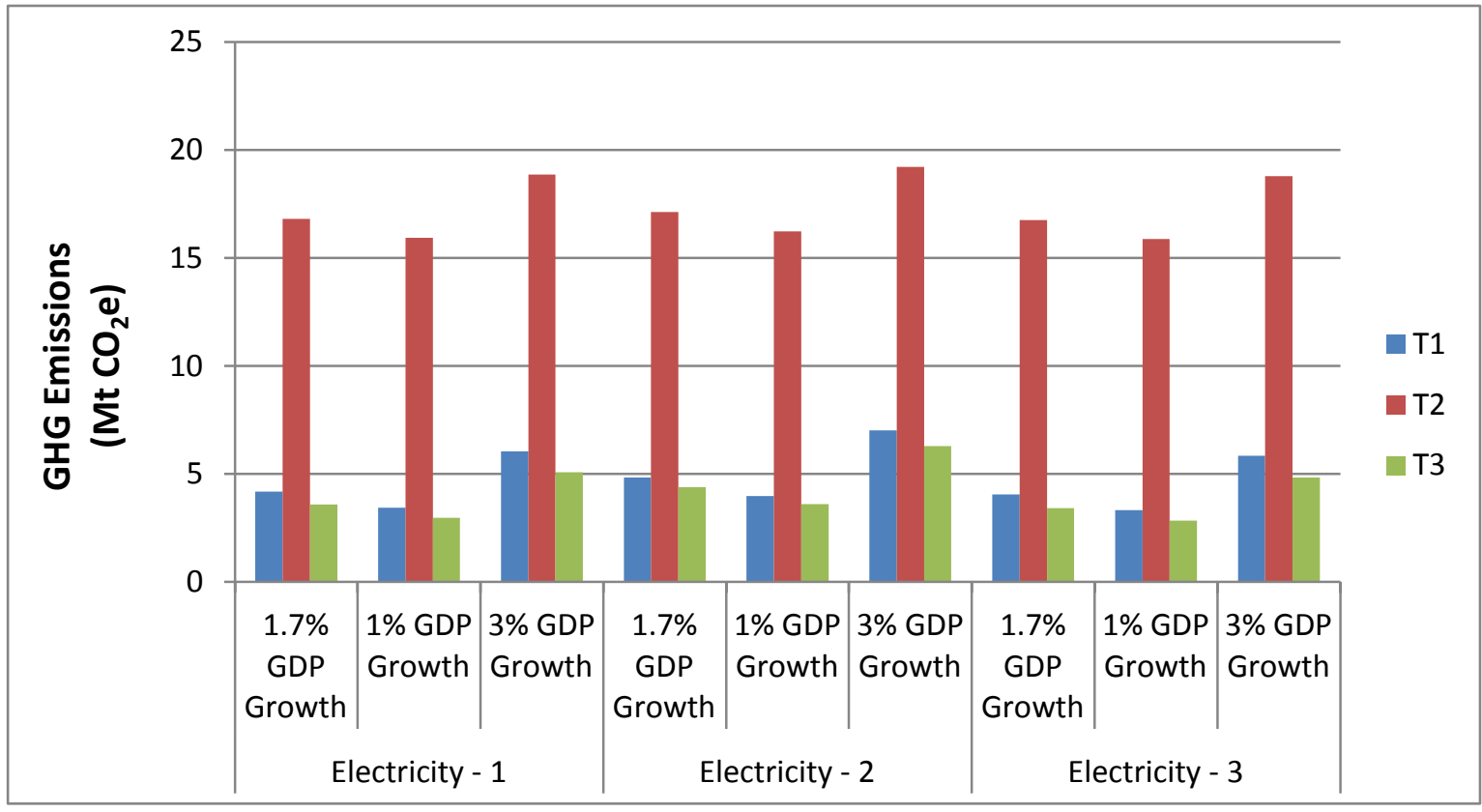

b)

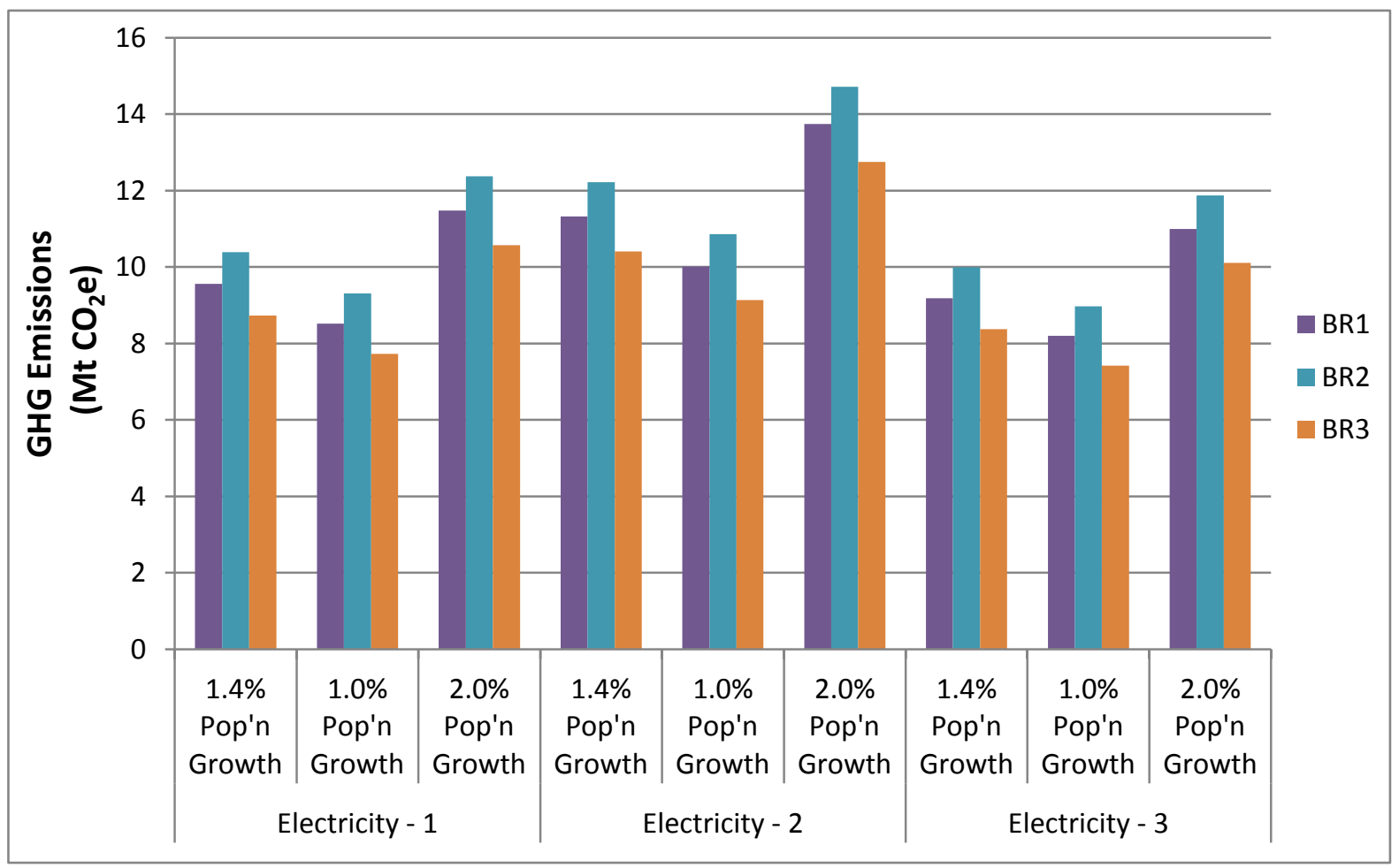


Cite as: Mohareb, EA \& Kennedy CA, 2014. Scenarios of technology adoption towards low-carbon cities. Energy Policy 66, 685-693

c)

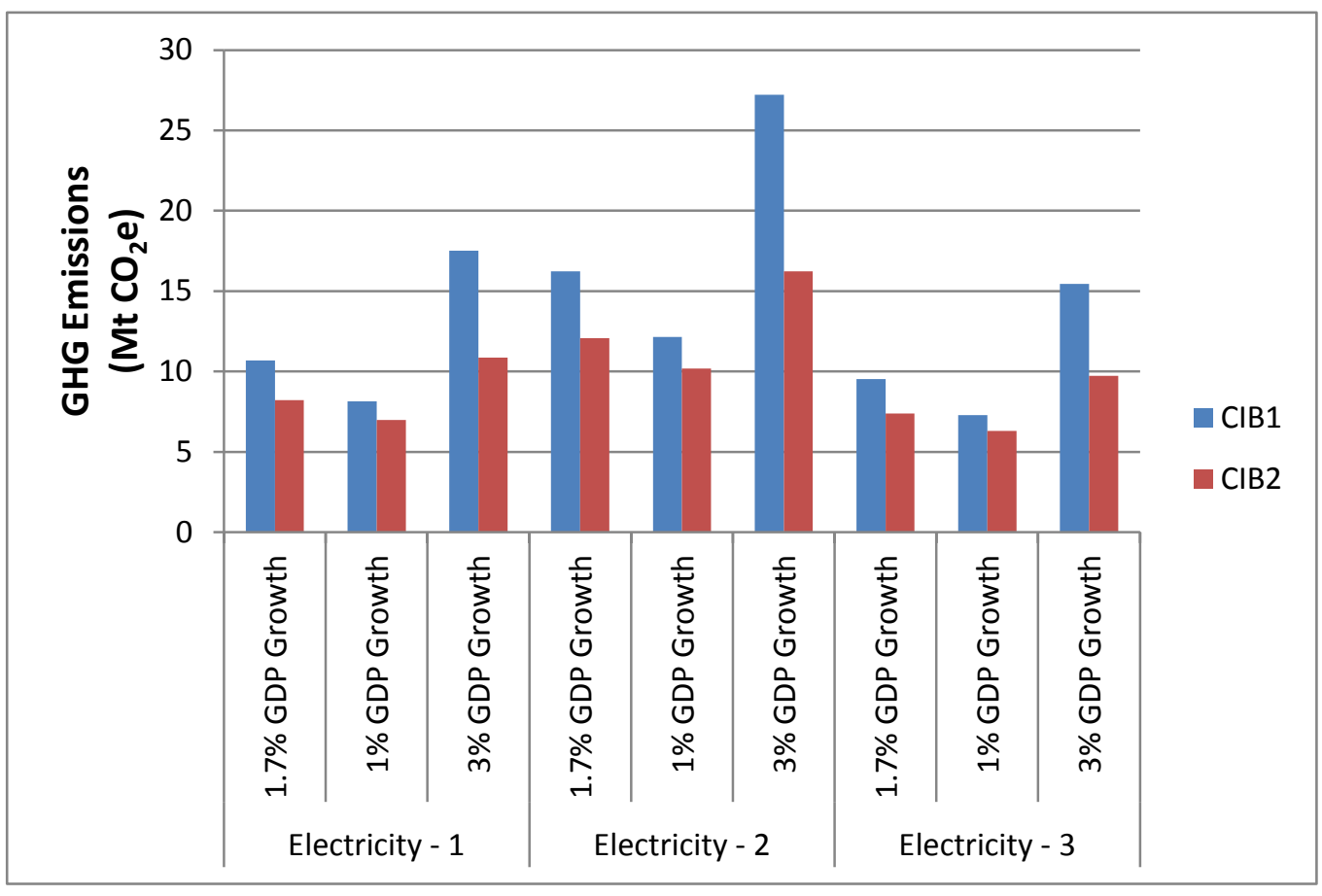

Figure 5: GTA GHG Emissions in 2050 from a) Transportation; b) Residential Buildings (Aggressive Building Code); c) Commercial/Institutional Buildings (Aggressive Retrofits)

\subsection{Transportation Scenario Results}

A few transportation policy implications can be drawn from the results of the PURGE model for the scenarios applied above. From transportation, municipalities and higher levels of government must discourage continued use of ICEVs (even those that are more efficient) as an important component of the vehicle fleet. From Figure 5a, all T2 scenarios (those that include ICEVs) result in future emissions greater than $15 \mathrm{Mt}$, while focusing on electricbased vehicles tends to result in 2050 emissions lower than $5 \mathrm{Mt}$. The lowest emissions result in 2050 from transportation when applying a T2 scenario was 15.9 Mt (assuming low GDP growth and a low carbon intensity electricity grid). Alternatively, biofuels that approach net carbon neutrality over their life cycle could also help achieve significantly lower emissions. Cities dependent on private vehicles due to low residential densities will require infrastructural support suitable to their regional context (e.g. public charging stations, 
Cite as: Mohareb, EA \& Kennedy CA, 2014. Scenarios of technology adoption towards low-carbon cities. Energy Policy 66, 685-693

battery-replacement stations, hydrogen fuelling stations) or a stable source of low carbon fuels to ensure adoption of these technologies will be successful. This support will likely have to be installed in advance to reduce concerns associated with range anxiety that would inhibit adoption in the near term.

The case in which hydrogen vehicles become a dominant technology mostly resulted in lower emissions than the PHEV / BEV / HEV mix, due to the elimination of HEVs; comparing T1 $\&$ T3 in the most effective emissions reduction case (using "Electricity-3" and an average

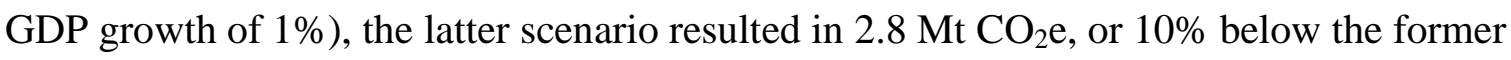
(Figure 2a), with a large share of emissions coming from legacy ICEVs in the vehicle stock.

Since the transportation scenarios described above did not achieve the $80 \%$ emissions reduction target, further analysis was conducted by applying reductions in vehicle usage associated with the expansion of regional transit. The model runs above assume 23,000 km as the vehicle kilometres traveled (VKT) in the first year of ownership, which then declines exponentially over the life of the vehicle. It is possible that investments in regional transit would reduce the average VKT of vehicles in the area. The GTA's regional transportation planning authority has targeted a reduction in personal vehicle work trips by approximately 35\% by 2035 (Metrolinx, 2010; Data Management Group, 2008). Assuming annual vehicle use will decline by the same fraction (starting at $15,000 \mathrm{~km}$ in the first year of ownership), GHG emissions would be reduced to $1.8 \mathrm{Mt} \mathrm{CO}_{2} \mathrm{e}$, slightly greater than the transportation target of 1.7 Mt. It should be noted that this does not consider emissions from public transportation, from which it is forecasted that roughly $1 / 3$ of all work trips in 2035 , and applies the same mode share reductions to non-work trips (68\% of all trips made by residents of the GTA; Data Management Group, 2008), making the 35\% reduction in annual VKT an optimistic projection. Correspondingly, alternative modes would also require low carbon 
Cite as: Mohareb, EA \& Kennedy CA, 2014. Scenarios of technology adoption towards low-carbon cities. Energy Policy 66, 685-693

energy for their operation. This emphasizes that even ambitious targets for mode shifting will likely not achieve the depths of reductions cities require and should be accompanied by equally aggressive targets to facilitate the adoption of alternative vehicle technologies.

In addition to technological approaches to achieving emission reductions in transportation, behavioral change will also play a role towards lowering transportation demand. Pricing mechanisms such as higher parking fees, vehicle/fuel taxes, pay-as-you-drive schemes, highway tolls and area pricing have been used in a number of jurisdictions in reducing congestion and vehicle emissions (Sustainable Infrastructure Group, 2010). These approaches provide the dual benefit of mode shifting and revenue generation (for the benefit of public transportation). Of these options, fuel taxes, higher parking fees and high occupancy toll lanes are being considered in the Greater Toronto Area (Metrolinx, 2013). Price increases in energy in general (electricity and fossil fuels) will also encourage demand reductions in all sectors.

It is also worth noting that while the GTA is attempting to address commuting through the implementation of major public transportation infrastructure projects, housing growth has continued in green field developments both within the GTA and its hinterland (i.e. bedroom communities, such as the Cities of Guelph or Barrie; Statistics Canada, 2012). This trend may drive further growth in GHG emissions for the region.

\subsection{Buildings Sector Scenario Results}

\subsubsection{Residential Buildings Scenario Results}

Aggressive building code updates were considered for residential buildings, but the energy performance of the existing stock slows emissions reductions. The lowest achievable residential building stock emission scenario from the options in Table 1 was a $31 \%$ reduction 
Cite as: Mohareb, EA \& Kennedy CA, 2014. Scenarios of technology adoption towards low-carbon cities. Energy Policy 66, 685-693

below 2010 levels. Further scenario analysis was conducted with this scenario, though applying a much more aggressive building code improvement schedule, with a net zero standard by 2026 and a Nordic passive house standard by 2031 (this scenario implies a 60\% intensity reduction in 2026, followed by a further $40 \%$ cut of the 2026 figure in 2031 , respectively; Norton and Christensen, 2007; Nieminen and Holopainen, 2010). This would adjust new building thermal energy use to roughly $10 \%$ of 2010 's new construction. This scenario achieves a slightly greater GHG emission reduction, with residential building emissions reduced to $37 \%$ below 2010 levels.

To further reduce emissions under this very aggressive building code revision scenario, apartment retrofits were modeled using the maximum reductions suggested by Toronto's “Tower Renewal Guidelines", regardless of vintage $(85.46 \%$ and $16.56 \%$ of natural gas and electricity use, respectively; Kesik and Saleff, 2009). Apartment retrofits were selected since there is currently a strategy in place for the complete retrofitting of the existing multi-unit residential building stock (Kesik and Saleff, 2009). However, this provided an emissions projection that was $41 \%$ below 2010 levels. This emphasizes that somewhat aggressive single-family housing retrofits, rigorous building code changes and the targeting of multi-unit residential buildings will not have the necessary impact on residential emissions; policy that encourages deep retrofits to the existing single-family building stock (including the complete replacement of natural gas furnaces and water heaters with electrical-based technologies such as geoexchange systems or electric tankless water heaters) or faster demolition and reconstruction with lower energy buildings (which would be more capital intensive, but also more effective in achieving deep reductions in energy demand; Dong et al, 2005) are the most urgent, as single family homes contribute more than $80 \%$ of the GTA's residential natural gas energy demand in 2050 in this latter scenario. 
Cite as: Mohareb, EA \& Kennedy CA, 2014. Scenarios of technology adoption towards low-carbon cities. Energy Policy 66, 685-693

Rising affluence may also put upward pressure on GHG emissions, given the existing market desire to increase residential floor area and the trend toward lower occupancy rates. These are not assessed in the scenarios above (see Table S2.1 for the values used in the GTA here) and must be targeted in regional policy to avoid negating efficiency gains.

\subsubsection{Commercial and Institutional Sector Scenario Results}

Commercial and institutional buildings appear to present the biggest challenge in reducing GHG emissions, with emissions declining 47\% versus 2010 in the most aggressive scenario applied above. To assess the impact of a further decline in floor space intensity ( $\mathrm{m}^{2} /$ GDP) for various sectors, a slightly different scenario was run that applied recent patterns in floor space requirement to 2050 (Office of Energy Efficiency, 2010). With the changes in GDP intensity of the C/I sector, floor area per \$GDP are generally reduced and a 55\% reduction in GHG emissions is achieved compared to 2010 (this scenario also applies the aggressive improvements in new building performance, low GDP growth and carbon-free electricity grid scenarios stated in Table 1). Even applying an assumption of a continued average annual decline in energy intensity of $1 \%$ in all sectors beyond 2025 produced reductions of $62 \%$ compared to 2010, well above an $80 \%$ target from a 1990 baseline (given that emissions from this sector have increased between 1990-2010).

There are several policy implications for C/I buildings. First, incentives to renovate the existing $\mathrm{C} / \mathrm{I}$ building stock are required - any scheme where a split incentive exists (i.e. a disconnect between property ownership/management and utility costs) will not address emissions on a wide enough scale by simply relying on market forces. Second, aggressive changes to the building code are also required; this is in spite of the potential for the rental market to drive change exemplified by the rapid growth in LEED-registered construction in 
Cite as: Mohareb, EA \& Kennedy CA, 2014. Scenarios of technology adoption towards low-carbon cities. Energy Policy 66, 685-693

the non- residential sector (20\% of all new construction in this sector in 2008 was LEEDregistered; Yudelson, 2010). Third, the scenarios we assessed for high performance buildings may be unrealistic for tall buildings; the model assumes all new construction of office buildings will be net zero-energy by 2050 . This is unlikely unless restrictions are placed on office building heights, as there are limitations on the height of net-zero buildings (Phillips et al, 2009). Finally, emissions reductions should also come through the elimination of physical spaces for providing commercial/institutional services, and through deeper retrofits and/or demolition and reconstruction of existing service spaces.

\subsection{Increases in Electrical Energy Demand}

While per capita energy demand is observed to decline as a result of the efficiency gains in the transportation and buildings sectors, absolute energy demand is projected to increase with growth in population and economic activity. Additionally, electricity demand may also increase due to other end-uses not captured in this model (e.g. water/wastewater treatment, street lighting). Examining the quantity of energy demand projected here provides the scope of energy requirements from non-fossil alternatives. Residential buildings in the GTA will require a $34 \%$ increase in total electricity supplied, over 19 TWh per year, in the most optimistic estimate (including implementation of the "passive house" building code by 2031 and the greatest feasible retrofits suggested by Kesik and Saleff, 2009). Commercial buildings see a decline in demand if using the scenario of continued contraction in the floor space per \$GDP, with electricity demand at roughly $24 \%$ lower than 2010 levels at 24 TWh in 2050. These two sectors give a building electricity demand of 43 TWh (includes a line loss assumption of $10 \%)$. 
Cite as: Mohareb, EA \& Kennedy CA, 2014. Scenarios of technology adoption towards low-carbon cities. Energy Policy 66, 685-693

Examining the transportation sector, electrical energy demand in the most optimistic scenario (T3, 35\% lower annual VKT demand, with a low-carbon grid and low rates of economic and population growth) is approximately $6.5 \mathrm{TWh}$. The resulting electricity demand for building and transportation sectors is roughly $50 \mathrm{TWh}$. It is assumed that $100 \%$ of this will be supplied by zero-carbon electricity generation by 2050 in this scenario; for the sake of comparison, $24.8 \%$ (37.2 TWh) of the entire province of Ontario's electricity was supplied by renewables in 2011 (IESO, 2012).

Natural gas consumption is also reduced in the aggressive cases discussed above, with commercial / institutional demand declining 28\% versus 2010 (77,300 TJ in 2050) and residential demand dropping by $27 \%$ compared with 2010 figures (120,000 TJ in 2050). To provide context for this, one estimate suggests that the current biogas potential in Ontario from food waste and manure would be on the order of 17,000 TJ (Agrienergy Producers Association of Ontario, 2011).

\subsection{Conclusions}

By applying scenarios that have been drawn from prominent literature sources, the technology adoption projections made here suggest that it will be difficult for the GTA (and likely other post-WWII cities) to attain emission reductions on the order of $80-95 \%$ below 1990 levels through technology stock turnover and adoption rates. Renewable electricity capacity must be increased significantly in the near term in all jurisdictions, especially when considering that emissions targets will be difficult to meet in this jurisdiction which is already dependent on low-carbon energy for the majority of its generation. Alternatively, the import of electricity from neighbouring low-carbon jurisdictions (e.g. Manitoba or Quebec, in the case of Ontario) could also serve to reduce the carbon intensity of the provincial electricity 
Cite as: Mohareb, EA \& Kennedy CA, 2014. Scenarios of technology adoption towards low-carbon cities. Energy Policy 66, 685-693

grid. Fundamental changes in the pathway through which energy services are delivered and the way that energy is consumed must be considered as long-term policy goals, especially in the face of increasing populations and economic growth (expected in most regions globally). Aside from urban sink enhancement (which is generally limited in its scope due to cost or relatively small carbon storage capacity; Mohareb and Kennedy, 2012), pursuing demand reduction through behavioural change strategies (building conditioning and private transportation energy demand reduction; Dietz et al, 2009; Ramaswami et al, 2012) must be coupled with technological change in order to lower emissions to levels that will mitigate the risk of climatic change.

Dematerialization of the economy (when considering a significant proportion of a developed world city's GHG emissions occur outside of their own urban boundaries through embodied emissions related to resource and goods consumption; Kennedy et al, 2012; Weber et al., 2008; Lenzen \& Peters, 2009) must also be encouraged in parallel, towards a truly lowcarbon city. It is possible that technological change in information systems could facilitate the acceptance of such strategies, such as through improved telecommuting, greater emphasis being placed on digital consumption (over physical goods and exchange spaces), or "smart" buildings (those with sophisticated control systems). There is no clear or simple strategy that can be applied universally for global cities on the pathway to a low-carbon future, though it is clear that cities must work to identify strategies within their individual context, and that action must be swift and aggressive in its approach, if the IPCC's 2050 targets are to be met. Additionally, emission reductions may be borne disproportionately in areas across the country, reducing the need for all cities to achieve reductions on the order of $80-95 \%$. Higher levels of government must actively coordinate both urban and rural efforts to reduce emissions to the necessary levels, through targeted policies and programs. Finally, the 
Cite as: Mohareb, EA \& Kennedy CA, 2014. Scenarios of technology adoption towards low-carbon cities. Energy Policy 66, 685-693

importance of local adaptation measures to address the severe implications of failing to reduce GHG emissions is emphasized by the results of this study, given that similar challenges are faced by many of the world's largest urban emitters.

\section{$\underline{\text { References }}$}

Bioenergy Producers Association of Ontario, 2011. Biogas Potential in Ontario - Briefing Note. [Online] Available HTTP: http://www.apao.ca/apaoExp/images/uploads/documents/2010/APAO Briefing_Note_Biogas_Potential_in Ontario.pdf. Accessed October 23, 2012.

C40 Cities, 2011. C40 Cities - Climate Leadership Group. [Online] Available HTTP: http://www.c40cities.org/. Accessed September 4, 2013.

Chan, C. C., 2002. The state of the art of electric and hybrid vehicles. Proc IEEE, 90, 247-275.

Chu, S., \& Majumder, A., 2012. Opportunities and challenges for a sustainable energy future. Nature, 488, 294-303

City of Toronto, 2011. City of Toronto Annual Demolition/Construction Permits. Personal communication, Ryan Persaud, City of Toronto, May 2, 2011

CivicAction, 2011. The Living City Report Card 2011 - An assessment of the environmental health of the Greater Toronto Area. [Online] Available HTTP: http://www.thelivingcity.org/lcrc4l, Accessed September 3, 2013.

CivicAction, 2012. Race to Reduce. [Online] Available HTTP: http://racetoreduce.ca/ Accessed October 22, 2012.

Data Management Group, 2008. Transportation Tomorrow Survey - 2006, 2001, 1996, 1986 Travel Summaries for the Greater Toronto and Hamilton Area $\left(5^{\text {th }}\right.$ Report of the 2006 TTS Series). [Online] Available HTTP: http://www.dmg.utoronto.ca/transportationtomorrowsurvey/index.html, Accessed October 22, 2012.

Dietz, T., G.T. Gardner, J. Gilligan, P.C. Stern, \& M.P. Vandenbergh, 2009. Household actions can provide a behavioral wedge to rapidly reduce US carbon emissions. Proceedings of the National Academy of Sciences, 106(44), 18452-18456 . 
Cite as: Mohareb, EA \& Kennedy CA, 2014. Scenarios of technology adoption towards low-carbon cities. Energy Policy 66, 685-693

Dong, B. Kennedy, C.; Pressnail, K., 2005. Comparing life cycle implications of building retrofit and replacement options. Canadian Journal of Civil Engineering, 32, 1051-1063.

Government of Ontario, 2009. A Plan for Ontario: 1 in 20 by 2020 - The next steps towards greener vehicles in Ontario. [Online] Available HTTP: http://news.ontario.ca/mto/en/2009/07/a-plan-for-ontario-1-in-20-by2020.html, Accessed online October 5, 2012.

Grubler, A., 1997. Time for a change: On the patterns of diffusion of innovation. IEEE Engineering Management Review, 25(2), 96-105.

Grubler, A., Nakicenovic, N. and Victor, D.G., 1999. Dynamics of energy technologies and global change. Energy Policy, 27, 247-280.

Harvey, L. D. D., 1993. Tackling urban $\mathrm{CO}_{2}$ emissions in Toronto. Environment, 35, 16-20+38.

Hoornweg, D., Sugar, L., and Gomez, C.L.T., 2011. Cities and greenhouse gas emissions: moving forward. Environment and Urbanization, 23(1), 207-227.

Independent Electricity System Operator, 2012. Composition of Ontario's Electricity Supply Mix Continues to Change. [Online] Available HTTP: http://www.ieso.ca/imoweb/media/md newsitem.asp?newsID=5930, Accessed, October 22, 2012.

IPCC, 2007. Climate Change 2007: Mitigation. Contribution of Working Group III to the Fourth Assessment Report of the Intergovernmental Panel on Climate Change [B. Metz, O.R. Davidson, P.R. Bosch, R. Dave, L.A. Meyer (eds)], Cambridge University Press, Cambridge, United Kingdom and New York, NY, USA.

International Energy Association, 2009. Transport, Energy and $\mathrm{CO}_{2}$ : Moving Toward Sustainability.

Jacobson, M. Z. \& Delucchi, M. A., 2011. Providing all global energy with wind, water, and solar power, Part I: Technologies, energy resources, quantities and areas of infrastructure, and materials. Energy Policy, 39, 1154-1169.

Kennedy, C., J. Steinberger, B. Gasson, Y. Hansen, T. Hillman, M. Havránek, D. Pataki, A. Phdungsilp, A. Ramaswami, and G. V. Mendez, 2009. Greenhouse gas emissions from global cities. Environmental Science and Technology, 43, 7297-7302 (2009). 
Cite as: Mohareb, EA \& Kennedy CA, 2014. Scenarios of technology adoption towards low-carbon cities. Energy Policy 66, 685-693

Kennedy, C.A., Demoulin, S., \& Mohareb, E., 2012. Cities reducing their greenhouse gas emissions. Energy Policy, 49, 774-777.

Kesik, T., \& Saleff, I., 2009. Tower Renewal Guidelines. University of Toronto. Available Online: http://www.daniels.utoronto.ca/files/TowerRenewalGuidelines.pdf, accessed October 22, 2012

Krajačić, G.; Duić, N.; Zmijarević, Z.; Mathiesen, B. V.; Vučinić, A. A.; Da Graa Carvalho, M., 2011. Planning for a $100 \%$ independent energy system based on smart energy storage for integration of renewables and CO2 emissions reduction. Appl. Therm. Eng., 31, 2073-2083.

Laboratory for Energy and Environment, 2008. On The Road in 2035: Reducing Transportation's Petroleum Consumption and GHG Emissions. MIT LFEE Report No. LFEE 2008-05 RP

Lave, L., Maclean, H., Hendricson, C., and Lankey, R., 2003. Life cycle analysis of alternative automobile fuel/propulsion technologies. Environment Science \& Technology, 34, 3589-3605.

Lenzen, M., \& Peters, G.M., 2009. How city dwellers affect their resource hinterland - A spatial impact study of Australian households. Journal of Industrial Ecology, 14(1), 73-90.

McKinsey and Co., 2009. Unlocking Energy Efficiency in the US Economy. [Online] Available HTTP: http://www.mckinsey.com/client_service/electric_power_and_natural_gas/latest_thinking/unlocking_energy_eff iciency in the us economy Accessed October 5, 2012.

Meinshausen, M., N. Meinshausen, W. Hare, S. C. B. Raper, K. Frieler, R. Knutti, D. J. Frame, and M. R. Allen, 2009. Greenhouse-gas emission targets for limiting global warming to 2 C. Nature, 458, 1158-1162 .

Metrolinx, 2010. The Big Move - Transforming Transportation in the Greater Toronto and Hamilton Area. [Online]. Available HTTP: http://www.metrolinx.com/thebigmove/en/default.aspx. Accessed October 22, 2012

Metrolinx, 2013. Investing in Our Region, Investing in Our Future. [Online]. Available HTTP: http://www.metrolinx.com/en/regionalplanning/funding/IS_Full_Report_EN.pdf. Accessed September 3, 2013

Ministry of Municipal Affairs and Housing, 2010. The Building Code - Energy Efficiency and Barrier-Free Access. [Online] Available HTTP: http://www.mah.gov.on.ca/Page7154.aspx, accessed October 22, 2012. 
Cite as: Mohareb, EA \& Kennedy CA, 2014. Scenarios of technology adoption towards low-carbon cities. Energy Policy 66, 685-693

Möllersten, K.; Yan, J.; Moreira, J. R., 2003. Potential market niches for biomass energy with CO2 capture and storage - Opportunities for energy supply with negative CO2 emissions. Biomass Bioenergy, 25, 273-285.

Mohareb, E.A., \& Kennedy, C.A., 2012. Producer and consumer carbon sinks for urban inventories. Journal of Industrial Ecology, 16(3), 303-316.

Mohareb, E.A.; Kennedy, C.A., 2012. Greenhouse Gas Emission Scenario Modeling for Cities using the PURGE Model - A Case Study of the Greater Toronto Area. Journal of Industrial Ecology, 16(6): 875-888.

Nakicenovic, N., 1986. The automobile road to technological change. Diffusion of the automobile as a process of technological substitution. Technological Forecasting and Social Change, 29, 309-340.

Natural Resources Canada, 2011. EcoENERGY Retrofit Program Results - Personal Communication (Louise Lewis) June 26, 2011

Nieminen, J., \& Holopainen, R., 2010. Concepts and Market Acceptance of a Cold Climate Passive House [Online] Available HTTP: http://www.nicis.nl/dsresource?objectid=209494\&type=org.

Norton, P., \& Christensen, C., 2007. Performance Results from a Cold Climate Case Study for Affordable Zero Energy Homes. NREL Conference Paper NREL/CP-550-42339.

Office of Energy Efficiency, 2010. Comprehensive Energy Use Database - Ontario. [Online] Available HTTP: http://oee.nrcan.gc.ca/corporate/statistics/neud/dpa/comprehensive tables/index.cfm Accessed October 22, 2012

Ontario Ministry of Finance, 2010. Ontario Population Projections: 2009-2036.

Ontario Ministry of Energy, 2011. Ontario's Long-Term Energy Plan. [Online] HTTP: http://www.energy.gov.on.ca/docs/en/MEI_LTEP_en.pdf. Accessed September 3, 2013

Pacala, S. \& Socolow, R., 2004. Stabilization wedges: solving the climate problem for the next 50 years with current technologies. Science 305, 968-972.

Pearre, N. S.; Kempton, W.; Guensler, R. L.; Elango, V. V., 2011. Electric vehicles: How much range is required for a day's driving? Transportation Research Part C: Emerging Technologies, 19, 1171-1184.

Phillips, D., Beyers, M., \& Good, J., 2009. How high can you go? ASHRAE J. 51, 26-36. 
Cite as: Mohareb, EA \& Kennedy CA, 2014. Scenarios of technology adoption towards low-carbon cities. Energy Policy 66, 685-693

Ramaswami, A., M. Bernard, A. Chavez, T. Hillman, M. Whitaker, G. Thomas, \& M. Marshall, 2012.

Quantifying Carbon Mitigation Wedges in U.S. Cities: Near-Term Strategy Analysis and Critical Review.

Environmental Science and Technology, 46, 3629 - 3642 (2012).

Romm, J. J., 2004. The Hype about Hydrogen-We can't use hydrogen's long-term potential as an excuse to avoid taking action now on reducing greenhouse gas emissions. Issues Sci. Technol., 20, 74-81.

Romm, J., 2006. The car and fuel of the future. Energy Policy, 34, 2609-2614.

Statistics Canada, 2006. Census of Population, Statistics Canada catalogue no. 97-559-XCB2006024

Statistics Canada, 2011. Ontario GDP, Chained 2002 Dollars. Table v15855724

Statistics Canada, 2012. Census Profiles 2011. [Online] Available HTTP: http://www12.statcan.gc.ca/censusrecensement/2011/dp-pd/prof/index.cfm. Accessed September 4, 2013.

Sustainable Infrastructure Group, 2010. Getting to Carbon Neutral: a Guidebook for Canadian Municipalities. [Online] Available HTTP: http://trca.on.ca/dotAsset/81361.pdf, Accessed September 3, 2013

US Green Building Council, 2011. LEED Projects and Case Study Directory. [Online] http://www.usgbc.org/LEED/Project/CertifiedProjectList.aspx, Accessed May 21, 2012.

Weber, C.L., Peters, G.P., Guan, D., \& Hubacek, K., 2008. The contribution of Chinese exports to climate change. Energy Policy, 36, 3572-3577.

Yudelson, J., 2010. In Greening existing buildings; McGraw-Hill: New York. 